\title{
Biopeptides of milk: caseinophosphopeptides and mineral bioavailability
}

\author{
Saïd BouHALlaB ${ }^{a *}$, Dominique Bouglé ${ }^{\mathrm{b}}$ \\ a Science et Technologie du lait et de l'œuf, UMR 1053 INRA-Agrocampus, \\ 65 rue de Saint Brieuc, 35042 Rennes Cedex, France \\ ${ }^{\mathrm{b}}$ Laboratoire de physiologie digestive et nutritionnelle, CHU de Caen, Côte de nacre, \\ 14033 Caen Cedex, France
}

\begin{abstract}
The biological and physiological activities of milk proteins are partially attributed to several peptides encrypted in the protein molecules. These peptides can be liberated by enzymatic digestion in vitro and in vivo. Among the biologically active molecules, phosphorylated peptides (caseinophosphopeptides, CPP) are known to exert an effect on calcium metabolism but also on other minerals. While the existing discrepancy on the potential role of CPP on calcium availability has not been clarified, the results of our previous studies showed that a purified phosphopeptide ( $\beta(1-$ $25)$ ) exhibits a positive effect on iron bioavailability in vivo. Here we report the main results on the efficiency of $\beta(1-25)$ in the absorption and availability of iron as well as on the mechanism involved.
\end{abstract}

\section{milk / bioactive peptide / phosphopeptide / iron bioavailability}

\section{INTRODUCTION}

Milk proteins are today largely known for their high nutritional value. They include remarkable techno-functional properties largely exploited by food industries. Since the end of the 1980s, both research scientists and the industry have become increasingly interested in both the biological and physiological properties of these proteins. Indeed, over the last several years, it has been shown that these proteins (caseins, lactoserum proteins) have different biological activities in vitro and in vivo. Table I gives several examples of bioactive molecules from milk and their precise functions. Besides the activities of the intact molecules, we know today that these proteins are the precursors of different peptide sequences possessing varying biological activities.
Amongst these principal activities, there are anti-hypertensive, anti-thrombotic, immunomodulating, oligoelement transportation, enzyme inhibition or digestive function modulation effects [1]. As a consequence, these peptides are susceptible to interact in physiological mechanisms by regulating the necessary functions of the organism (digestion, immunity...). The evolution of the research in the sector of bioactive peptides from milk during the last 30 years is illustrated in Table II.

The bioactive peptides are generally generated in vitro by the action of diverse available digestive enzymes. They are also formed during the elaboration of milk products (cheese, yoghurt) under the action of endogenous enzymes of milk (plasmin, cathep$\sin .$. ) or of micro-organisms.

\footnotetext{
* Corresponding author: sbouhal@labtechno.roazhon.inra.fr
} 
Table I. Diversity of biological and physiological activities of proteins and peptides in milk.

\begin{tabular}{|c|c|c|c|c|c|c|}
\hline & \multicolumn{4}{|c|}{ Targeted functions } & \multicolumn{2}{|c|}{ Other activities } \\
\hline & Digestion & Thrombosis & Arterial pressure & Immunity & Anti-bacterial & Anti-cancers \\
\hline Serum proteins & & $\mathrm{x}$ & $\mathrm{x}$ & $\mathrm{x}$ & $\mathrm{x}$ & $\mathrm{x}$ \\
\hline Albumin serum & & & & & & $\mathrm{x}$ \\
\hline Lactoferrin & & $\mathrm{x}$ & & $\mathrm{x}$ & $\mathrm{x}$ & $\mathrm{x}$ \\
\hline$\alpha$-lactalbumin & & & & & & $\mathrm{x}$ \\
\hline Lactoperoxidase & & & & $\mathrm{x}$ & $\mathrm{x}$ & \\
\hline Peptides & $\mathrm{x}$ & $\mathrm{x}$ & $\mathrm{x}$ & $\mathrm{x}$ & $\mathrm{x}$ & \\
\hline Glycomacropeptide & $\mathrm{x}$ & $\mathrm{x}$ & & & $\mathrm{x}$ & \\
\hline Phosphopeptides & $\mathrm{x}$ & & & $\mathrm{x}$ & & \\
\hline
\end{tabular}

Table II. Evolution of research on biologically active milk-derived proteins and peptides.

\begin{tabular}{ll}
\hline Periods & Research and undertaken actions \\
\hline Years 1960-1970 & - Search for biological activities (opiates, mineral absorption) \\
& - In vitro tests, use of animals \\
Years 1980-1989 & - Extensive research of new activities \\
& - Research on in situ liberation of peptides \\
& - Study of other food proteins \\
& - In vivo tests \\
& - Development of processes for the production of fractions enriched in \\
& bioactive peptides \\
Years 1990-today & - Tests in the animal in severe conditions \\
& - Clinical studies \\
& - Development of ingredients with health claim \\
& - Studies on mechanisms of action \\
\hline
\end{tabular}

\section{PHOSPHOPEPTIDES AND BIOAVAILABILITY OF MINERALS}

The caseinophosphopeptides (CPP) are strongly phosphorylated peptides obtained by enzymatic digestion of caseins. As shown in Figure 1, CPP from $\beta, \alpha_{\mathrm{s} 1}, \alpha_{\mathrm{s} 2}$ caseins possess a common acidic motif composed of three phosphorylated serines followed by two glutamic acids. These molecules are available today on a large scale and are commercialised by different international companies. The CPP have a strong capacity to fix nutritionally interesting divalent cations such as calcium, iron or zinc, thus mak- ing them stable and soluble in different physico-chemical conditions in particular of $\mathrm{pH}[2,3]$. This mineral binding capacity is conferred by the acidic domain of the CPP. Due to this property, several researchers claimed that CPP are involved in intestinal absorption of minerals, in particular of calcium, with however, contradicting results: the CPP improve the absorption of calcium in the rat by limiting the precipitation of this mineral in the intestine and also the absorption of calcium and zinc in the human adult, but do not show a positive effect in other studies in the rat or pig. The reader may refer to recent reviews in this domain [4-6]. The origin of these differences may be of 


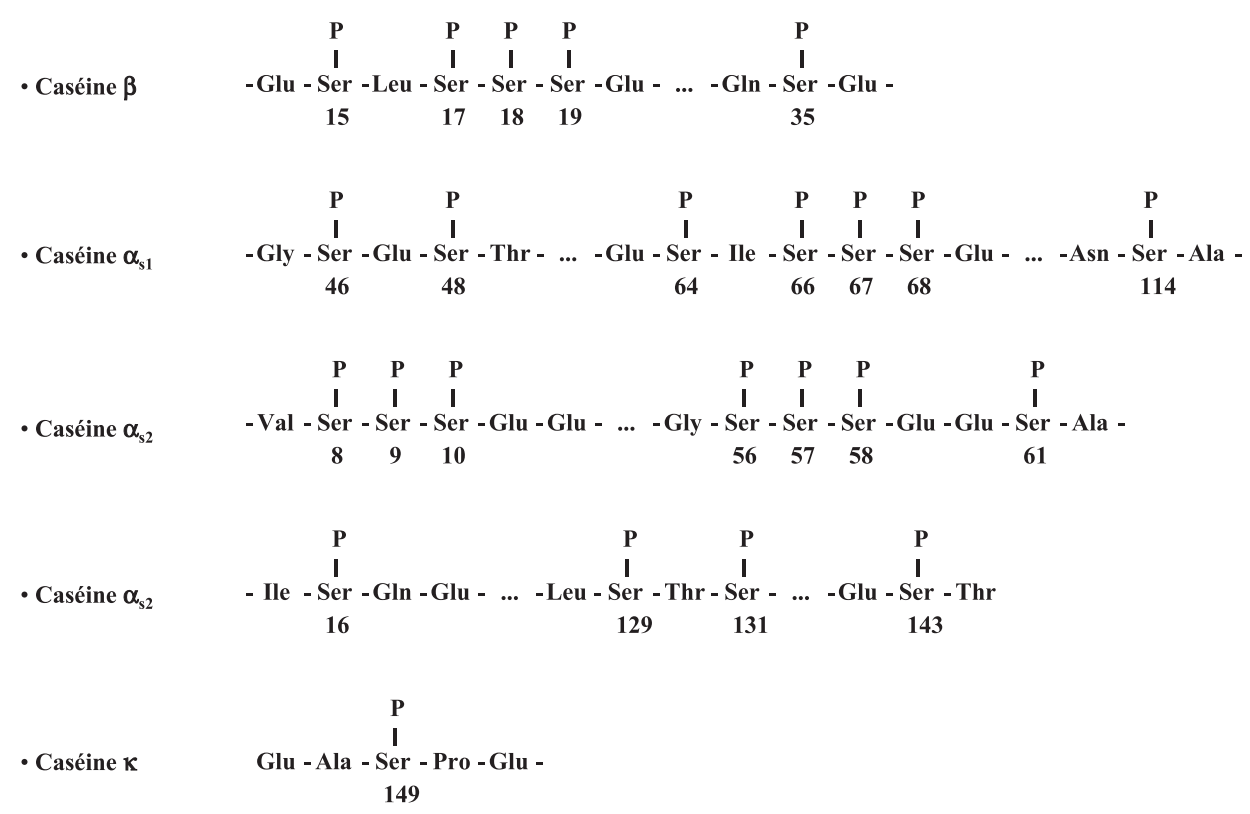

Figure 1. Sequences in amino acids of the casein derived phosphopeptides.

different orders: the experimental models studied, age and physiological state of the animal, length of administration, composition of the diet, complexity and variability in the composition of the CPP preparations used.

Current studies on the role of phosphopeptides in the use of calcium are focused on a better consideration of the different factors affecting the bioavailability of calcium on the one hand and on the exploration of the mechanisms involved on the other hand. Concerning this latter point, a recent study has shown that the phosphorylated region as well as the $\mathrm{N}$-terminal part are necessary for a positive effect of the phosphopeptides on the uptake of calcium by human cells in culture (HT-29) [7].

Even though there is a lot of literature on the potential role of these CPP in the absorption of calcium, little work is available, however, on other minerals and trace elements. A deficiency in trace elements represents a major public health problem, by their frequency and their functional conse- quences. For iron, the risk of a deficiency is major in developing countries, but it also represents a public health problem in France: 15-20\% of newborns and 20-30\% of women in child-bearing ages or pregnant have an iron deficiency [8].

Over the last several years, we have been developing a research programme on the role of CPP in the bioavailability of iron. In particular, we have used an approach that favours the use of a pure and well-characterised phosphopeptide in parallel with mixed CPP and their different fractions. The phosphopeptide studied is the $\beta(1-25)$ derived from bovine $\beta$-casein that contains 4 phosphoserine residues in its sequence (Fig. 1) and can fix 4 to 5 iron atoms with a high affinity $[2,9]$. At first, the studies in rats have allowed to show the efficiency of $\beta(1-25)$ on the absorption and bioavailability of iron [10], an efficiency that was confirmed in a first clinical study [11]. Then, the mechanism of absorption of iron associated with the phosphopeptide as well as the effect of the presence of other minerals 
(zinc) were studied using the perfusion of a ligated rat duodenal loop segment [12-14].

\section{PHOSPHOPEPTIDES AND IRON}

\subsection{Bioavailability of iron complexed to the $\beta(1-25)$ phosphopeptide}

The bioavailability of iron in the iron$\beta(1-25)$ phosphopeptide $(\mathrm{Fe} / \beta(1-25))$ was studied in the rat using metabolic and blood evaluations as well as iron concentration in the tissues of target organs (liver, spleen). As a comparison, two other forms of iron, inorganic $\left(\mathrm{FeSO}_{4}\right.$ or iron gluconate) and iron complexed to $\beta$-casein were also used. Two levels of intake were used: a pharmacological intake of $200 \mathrm{mg} \mathrm{Fe} \cdot \mathrm{kg}^{-1}$ of diet, the equivalent of a supplementation to correct a deficiency, and a dietetic intake of $40 \mathrm{mg}$ $\mathrm{Fe} \cdot \mathrm{kg}^{-1}$ of diet. The results obtained have shown that $\beta(1-25)$ is a good vector of the absorption and the bioavailability of iron. The group of animals having received the iron/phosphopeptide complex showed a better improvement in the blood parameters relative to the iron level in comparison with the groups having received iron as the two other forms. In addition, the $\mathrm{Fe} / \beta(1-25)$ group showed a stock of iron in the tissues (liver, spleen) which was higher than that of the $\mathrm{Fe} / \beta$ casein and $\mathrm{FeSO}_{4}$ groups. The concentrations of iron in the liver and spleen were 1.5 to 3 times higher with $\beta(1-25)$ than with $\mathrm{FeSO}_{4}$ or $\beta$ casein and this for the two initial intakes in iron [10]. These results obtained in the rat were confirmed in a preliminary clinical study, comparing $\mathrm{Fe} / \mathrm{\beta}(1-$ 25 ) and iron sulphate. The quantity of iron stocked in the organs seven days after the ingestion of a unique dosage is higher in the group having received the $\mathrm{Fe} / \beta(1-25)$ complex [11].

The positive results obtained with $\beta(1-25)$ cannot be maintained when the iron is already complexed with whole caseins or total phosphopeptides (CPP). The studies that we have done on the different phos- phopeptide fractions show that the biological effect is strongly dependent on the sequence of phosphopeptides and thus on its relative affinity towards iron atoms. The phosphopeptides derived from $\alpha_{\mathrm{s}}$ caseins, more strongly phosphorylated, have a tendency to decrease the quantity of iron available biologically [15]. The superiority of $\beta(1-25)$ as a vector as compared to the phosphopeptides of $\alpha_{\mathrm{s}}$-casein has also been observed recently in the uptake of calcium by culture cells [7]. These results underline the importance of the physicochemical properties of these complexes on the expression of their biological activity.

\subsection{Mechanism of absorption of the iron complexed to $\beta(1-25)$}

This study was performed ex-vivo on an isolated and perfused rat intestine. The first part concerned the analysis by comparative mass spectrometry of the molecules present in the luminal contents after perfusion with solutions containing $\beta(1-25)$ alone, the $\mathrm{Fe} /$ $\beta(1-25)$ complex or $\mathrm{FeSO}_{4}$. The results obtained suggest that the phosphorylated part of this vector i.e. the $\beta(14-24)$ central sequence, is the molecular entity implicated in the transfer of iron through the intestinal membrane [12]. In other respects, the use of specific inhibitors for the different metabolic pathways of transport permitted to explain in part the positive effect observed with the $\mathrm{Fe} / \beta(1-25)$ complex. The inhibitors used were the 2-4 dinitrophenol (DNP), an inhibitor of oxidative phosphorylation and/or phenylarsine oxide (PAO), an inhibitor of endocytosis. They were added into solutions containing iron either as the gluconate form or complexed with $\beta(1-25)$. As is shown in Table III, the percentage of iron absorbed was significantly higher in the group having received the $\mathrm{Fe} /$ $\beta(1-25)$ complex. For the two forms of iron, most of the iron absorbed $(65-70 \%)$ followed an energy-dependent transport pathway. The other part was absorbed by a passive pathway for inorganic iron. However, a non-negligible contribution of absorption 
Table III. Percent of iron absorbed after perfusion of isolated anaemic rat intestines and the different pathways implicated as a function of the form of iron used (Fe/gluconate versus $\mathrm{Fe} / \beta(1-25)$ ). The perfusions were performed with $50 \mu \mathrm{M}$ Iron.

\begin{tabular}{lcc}
\hline & Group perfused with Fe/gluconate & Group perfused with Fe/ $/(1-25)$ \\
\hline$\%$ of absorbed iron & $49 \pm 4.6$ & $55.5 \pm 3.4$ \\
By passive transportation & 16 & 9 \\
By active transportation & 33 & 37 \\
By endocytosis & - & 10 \\
\hline
\end{tabular}

by endocytosis (about $20 \%$ of absorbed iron) was observed in the $\mathrm{Fe} / \beta(1-25)$ group (Tab. III). Thus, a part of $\mathrm{Fe} / \beta(1-25) \mathrm{com}-$ plex seemed to be absorbed by an endocytosis phenomena, besides the usual pathways for ferruginous transport [13].

\subsection{Effect of other minerals (calcium, zinc)}

It is known that calcium and zinc ( $\mathrm{Zn}$ ) can affect or enter into competition with iron as a membranous receptor implicated in the transport of minerals towards the enterocyte. The study that we carried out showed that the use of $\beta(1-25)$ allows to strongly reduce the inhibiting effects of zinc and calcium on the absorption of iron by the isolated and perfused rat intestine. For a molar ration $\mathrm{Zn} / \mathrm{Fe}=5$, zinc inhibits about $50 \%$ of the absorption of iron. This rate of inhibition is reduced to $5 \%$ when iron has been previously fixed to $\beta(1-25)$ [14]. The same tendency was obtained in the presence of calcium. With a concentration in calcium two times higher than that of iron, the phosphopeptide reduces to half the inhibiting effect of calcium on the absorption of iron.

\section{CONCLUSION}

The presence of bioactive peptides in food proteins in general and in milk in particular is now well documented and constitutes both a scientific and technological challenge. It is important for the future to consider more thoroughly what the activities of these molecules become, their stability in the complex food matrices and how to master the different types of interactions between the molecule and the other constituents of a diet. The example of phosphopeptides shows that the efficacy of these molecules as a mineral vector is closely associated to the nature of the complexes formed. The physico-chemical properties of these complexes should be known in order to establish a relation between their structure and activity. This molecular approach of the problem is imposing itself more and more today as shown in the studies that have started appearing on the study of the mechanisms of action of bioactive peptides.

\section{ACKNOWLEDGEMENTS}

The authors thank Madame V. Picard for reading and correcting this manuscript.

\section{REFERENCES}

[1] Korhonen H, Pihlanto H. Bioactive peptides: new challenges and opportunities for the dairy industry. Aust J Dairy Technol 2003, 58: 129134.

[2] Brulé G, Fauquant J. Interactions des protéines du lait et des oligoéléments. Lait 1982, 62: 323-331.

[3] Meisel H, Schlimme E. Calcium and iron binding capacity of different fractions from in vitro proteolysis of casein. Kiel Milchwirtsch Forschungsber 1993, 45: 235-243. 
[4] Scholz-Ahrens KE, Schrezenmeir J. Effects of bioactive substance in milk on mineral and trace element metabolism with special reference to casein phosphopeptides. Br J Nutr 2000, 84 (Supppl 1): S147-S153.

[5] Camara-Martos F, Amaro-Lopez MA. Influence of Dietary Factors on Calcium Bioavailability. Biol Trace Elem Res 2002, 89: 43-52.

[6] Bouhallab S, Bouglé D. Rôle des caséinophosphopeptides dans l'absorption et la biodisponibilité des minéraux. In: Gaucheron F (Ed), Minéraux et produits laitiers, Tec \& Doc Lavoisier, Paris, 2004, p 763-780.

[7] Ferraretto A, Gravaghi C, Fiorilli A, Tettamanti G. Casein-derived bioactive phosphopeptides: role of phosphorylation and primary structure in promoting calcium uptake by HT-29 tumor cells. FEBS Lett 2003, 551: 92-98.

[8] Hercberg SG, Preziosi P. La déficience en fer au cours de la grossesse en France. Cah Nutr Diét 2000, 35: 13-23.

[9] Meisel H, Schlimme E. Calcium and iron binding capacity of different fractions from in vitro proteolysis of caseins. Kiel Milchwirtsch Forschungsber 1993, 45: 235-243.

[10] Aït-Oukhatar N, Bouhallab S, Arhan P, Maubois JL, Drosdowsky M, Bouglé D. Iron tissue storage and hemoglobin levels of defi- cient rats repleted with iron bound to the caseinophosphopeptide 1-25 of beta-casein. J Agric Food Chem 1999, 47: 2786-2790.

[11] Aït-oukhatar N, Pérès JM, Bouhallab S, Neuville D, Bureau F, Bouvard G, Arhan P, Bouglé D. Bioavailability of caseinophosphopeptide-bound iron. J Lab Clin Med 2002, 140: 290-294.

[12] Bouhallab S, Aït-Oukhatar N, Mollé D, Henry G, Maubois JL, Arhan P, Bouglé D. Sensitivity of $\beta$-casein phosphopeptide-iron complex to digestive enzymes in ligated segment of rat duodenum. J Nutr Biochem 1999, 10: 723727.

[13] Pérès JM, Bouhallab S, Bureau F, Neuville D, Maubois JL, Arhan P, Bouglé D. Mechanisms of absorption of caseinophosphopeptide bound iron. J Nutr Biochem 1999, 10: 215-222.

[14] Pérès JM, Bouhallab S, Bureau F, Maubois JL, Arhan P, Bouglé D. Reduction of iron/zinc interations using metal bound to the caseinophosphopeptide $1-25$ of $\beta$-casein. Nutr Res 1999, 19: 1655-1663.

[15] Bouhallab S, Cinga V, Ait-Oukhatar N, Bureau F, Neuville D, Arhan P, Maubois JL, Bougle D. Influence of various phosphopeptides of caseins on iron absorption. J Agric Food Chem 2002, 50: 7127-7130. 